DOI: $10.1515 / \mathrm{rpp}-2015-0028$

Postgraduate student, TETIANA HIZHYNSKA

Khmelnytskyi National University, Ukraine

Address: 11 Instytutska St., Khmelnytskyi, 29016, Ukraine

E-mail: ko130586@rambler.ru

\title{
PROFESSIONAL TRAINING PROGRAMS OF MASTERS IN ADULT EDUCATION AT UNIVERSITIES OF GERMANY
}

\begin{abstract}
The German experience in professional training of teaching staff in adult education has been analyzed; it has been clarified that modern educational programs of Bachelor and Master specialties are based on the basic educational program offered by Adult Education Sectional Commission of Pedagogical Sciences in Germany (DGfE); value-targeted and organizational and semantic issues of Masters' in Adult Education professional training in universities of Germany, defined according to andragogue profession's modern roles and functions have been considered. The purpose of Masters' in Adult Education professional training and the content of professional competencies have been revealed, the limits of andragogues' academic education at the graduate level have been outlined. Based on the theoretical analysis of university reference books common features of Master's programs of academic education in Adult Education / Continuous Education in universities of Germany have been found; the basic principles of the Master's programs realisation in German universities have been indicated. Special attention is paid to research and justification of organisation and structural elements of Master's programs in Adult Education / Continuous Education in Otto Friedrich University in Bamberg; the purpose and subject specialty have been revealed; the relation between theory and practical training has been established, the organization and the purpose of practical training abovementioned university have been described, professional prospects of graduates have been outlined.

Key words: teaching staff for adult education, professional training, educational program, professional competence, andragogue's training, modular program, curriculum, practical training.
\end{abstract}

\section{INTRODUCTION}

In modern Ukraine adult education has become increasingly important as it is an integral component of the education system so that adults' professional and personal level is improved. Given the fact that an adult is the center of andragogical activity, it has been proved that adult education requires special training methods and organization of training activities, so teaching staff of adult education should be specially trained. We could not but agree with the idea of L. Lukianova that "teacher andragogue is a subject of adult education, where a level of professional training plays an important role" (Лук'янова, 2014). Based on the idea that study and further taking into account European trends of educational systems development and evolutionary advanced nature of world educational policy largely affects the competitiveness of university education in Ukraine (Бідюк, 2014), it is necessary to consider the European experience. The studies of professional training of teaching staff in adult education have shown that EU countries are trying to keep up with modern trends and are striving for adjusting teaching staff training to current needs and social demands on the labour market. At present, in Germany there is a developed system 
of adult education teaching staff training, which includes two-stage academic education, additional education and advanced training programs and thus sets high demands for education quality and professional training. So, constantly introducing regular innovations Germany belongs to progressive countries and can be based on in establishing the most efficient ways for the professional training of teaching staff in adult education in Ukraine.

\section{THE AIM OF THE STUDY}

The article aims at studying professional training programs of Masters in Adult Education, the revelation of educational process organisation and peculiarities of Masters' in Adult Education practical training.

\section{THEORETICAL FRAMEWORK AND RESEARCH METHODS}

Being topical nowadays the phenomenon of continuous education requires extending knowledge and professionalism of teaching staff, which are primarily acquired during basic education. It should be mentioned that the formation of adult education departments and implementation of specialties for training of the teaching staff in adult education into higher education system in Germany have been observed since the mid-60s of the twentieth century and are seen by German researchers as an important stage in establishing andragogics' professionalization (Schemmann, Wittroth, 2005).

Theoretical analysis of modern literature has shown that there are a number of researches devoted to the study of adult education systems in other countries, the fields of adult education teaching staff activity, although the peculiarities of andragogues' professional training have not been studied enough. Researches on various aspects of adult education in foreign countries, particularly in relation to andragogues' professional training, are reflected in the works of Ukrainian scientists: L. Alekseeva, S. Arkhipova, N. Bidyuk, I. Litovchenko, L. Lukianov, O. Ohienko. Scientific works of such German scientists as R. Egetenmeyer, G. Graeßner, S. Lattke, P. Faulstich and others are of great interest.

Studies on the problem of andragogues' professional training in Germany have been carried out with the following research methods: theoretical analysis of literary sources and methodical documents, theoretical systematisation and generalisation.

\section{RESULTS}

For the establishment of an educational qualification model is required, which would provide core competencies and standards needed for adult education (AE) and guarantee the quality of educational offers, the basic two-stage system for the professional training of adult education teaching staff (Bachelor and Master's degrees) has been formed in Germany. Modern educational programs of Bachelor and Master's specialties are based on a basic education program (Kerncurriculum), offered by the Adult Education Sectional Commission of Pedagogical Sciences in Germany (DGfE). The basic education program for Bachelor / Master's pedagogical specialties in Adult Education / Continuous Education has been created to unify the educational processes of different universities, provide high mobility and enable an understanding of graduates of narrow specialisation (Kernprogram für konsekutive Bachelor, 2006). The very name of the program indicates that two cycles of andragogues' academic preparation retaining the continuity principle are described. This program is not an absolute standard and does not contain clear instructions on the forms of the educational process, and only covers the basic list of learning blocks, which are the necessary knowledge minimum of graduates in Adult Education / Continuous Education. The structural model of Master's degree accorded with basic educational program consists of 5 blocks (pedagogical sciences, professional qualification, adult education / continuous education, additional specialty, Master's thesis) and includes 120 points. 
The database of Hochschulkompass.de site dedicated to educational offers in Germany presents 17 Master's programs that in some way are related to the preparation of teaching staff in adult education. Only 5 programs include keywords Adult Education or Continuous Education, the rest of offers within the core specialty of pedagogical Sciences (Erziehungswissenschaft) contain only special profile or module relating to the abovementioned branch and provide graduates with an opportunity to work with adults. It should be noted that this article particularly describes programs with the keyword Adult Education.

According to university programs the teaching staff training in adult education is aimed at obtaining professionalism within specified qualification limits. During learning and practical classes a future andragogue acquires necessary professional, methodical and extra professional (social and personal) competencies needed for the future success of his professional work as an adult education teacher, and the continuous development and obtaining the abovementioned and additional competencies enable an actual andragogue to compete for workplaces and contribute to his recognition as a qualified specialist. Quite a wide range of competencies acquired during academic education is caused by diversity of an andragogue's professional roles and functions, including: research work, planning, learning, leading, consulting, management, arrangement, analysis and evaluation (Künzel, Keller, 2001). Studying German lexicographical sources it has been found out that professional competencies include, on the one hand, the basic knowledge of pedagogy and pedagogical terminology, comprehending the adult education establishing process, as well as educational and an adult's thinking processes, and, on the other hand, rather wide worldview and political awareness. Considering methodological competences one can emphasize the ability to organise meaningful and constructive trainings, the ability to develop effective teaching techniques, and effective usage of participation activation methods in learning process and leading group processes. Methodological competences are accumulated mainly during practical activity. Social competence comprises personal qualities needed for communication with other people. Social competences include the ability to communicate and interact with people, empathy, the ability to communicate in non-verbal level and teamwork. Such personal qualities as self-awareness, determination, diplomacy, extravertism, self-control and ability to organize, structurise and analyze are considered to be major elements of self-competence (Künzel, Keller, 2001).

According to the concept of the Bologna Process, the second level of basic academic education is Master's degree that provides narrow professional area of knowledge, if it has been successfully completed. Based on the university reference books' theoretical analysis such common features in Master's programs of academic education in Adult Education / Continuous Education in German universities have been outlined: theoretical and / or practical profound study of chosen program based on the knowledge gained at Bachelor's degree; application terms include completed education with obtaining educational qualification of Bachelor in Pedagogical Sciences or other equated program that has been approved by the special Committee and the minimum passing score of 2,5-3; two-year fulltime learning according to Credit Transfer and Accumulation System, with the maximum obtaining of 120 credits; theoretical courses, research and practical activities; certain forms of learning activities (lectures, seminars, practical lessons, self-study, colloquia); writing Master's thesis and compulsory colloquia attendance; obtaining Master of Arts qualification (MA) upon successful completion of learning.

Rather a good example of teaching staff quality training in adult education can be Master's program in Adult Education / Continuous Education in Otto Friedrich University 
in Bamberg, Germany, where the training is provided by teaching staff of andragogics department (Adult Education presently), which was established in the $70 \mathrm{~s}$ of the last century and currently cooperates with world professors in the abovementioned scientific branch. The subject of the study within practice-oriented program Adult Education / Continuous Education is foundations and methods of communication with adult students, methods of imparting and presenting professional knowledge, institutional, legal and organizational conditions for adult education and, in addition, necessary competencies and key qualifications to perform further successful professional activity. Graduates should know the basics of pedagogy and have profound knowledge in adult education sphere, the ability for individual scientific work, applied and professional skills as well as the ability to carry out educational, leading, administrative and organisational functions (Studien- und Fachprüfungsordnung für den Masterstudiengang Erwachsenenbildung, 2012).

The preconditions for admission to Master's program of the abovementioned university are: six-term prior learning in higher educational establishment with obtaining educational qualifications and a minimum passing score of 2,5 ; prior practice by profession (225 hours); competence in empirical research methods confirmed by an appropriate module completion (at least 15 points) (Studien- und Fachprüfungsordnung für den Masterstudiengang Erwachsenenbildung, 2012).

It is advisable to consider the content and goals of so-called "prior practice" (Vorpraktikum), which is obligatory for admission. This kind of practice should be realized in establishments, groupings or enterprises where learning and work with adults are carried out in the relevant scientific research institutions. The main goal of prior practice is an applicant's final determination in professional choice. Prior practice is followed by writing practice analysis report. It should be stylistically correct and have a reflective nature. If, for some reason, an applicant has not passed prior practice, as an exception he may be admitted to study upon the condition of passing it (concurrently with studying) no later than before the second term (Schemmann, Wittroth, 2005).

Theoretical analysis of module reference book on Adult Education / Continuous Education in Bamberg university has shown the program with the maximum of 120 points is divided into the following four training blocks: "Pedagogy", "Adult Education / Continuous Education", "Professional orientation", "Master's thesis". During all training period students must pass 13 modules, 12 of them are obligatory (Pflicht) and one is obligatory with choice possible (Wahlpflicht). Within the training block "Pedagogy" one obligatory module with choice possible and 3 obligatory modules are studied: "Standards and Goals, foundations and history of upbringing and education", "Empirical research methods (information gathering / research / analysis)", "Empirical research methods (application)". The second training block "Adult Education / Continuous Education" is the largest by volume and contains the following modules: "Basic concepts and approaches in Adult Education / Continuous Education", "Foundations, theories and field activities in Adult Education / Continuous Education", "Field activities and competences in Adult Education / Continuous Education", "Theories, research approaches and framework in Adult Education / Continuous Education. The third training block "Professional orientation" includes "General qualification competences in Adult Education / Continuous Education". The last training block "Master's thesis" contains only one module of the same name (Modulhandbuch. Masterstudiengang Erwachsenenbildung, 2013). Analyzing the entire list of modules and their characteristics it is quite obvious that self-study prevails classroom work. All subjects are taught in German. The English language proficiency 
should be equaled to B2, though. It is specified by the need to study a large number of English professional literature.

Before studying each graduate should make an individual learning plan with the option for 30 term credits. It should be indicated that the programs of German universities are different from the Ukrainian ones. In the module reference book there is a list of all required modules that must be completed during 4 terms, thus each module contains the recommendation, which term it is better to include in the student's individual plan. An interesting feature of the educational process is the requirement to submit a written application for participation in training activities as seminars and practical lessons have quantitative restrictions for participants.

The importance in Master's training of andragogues in Otto Friedrich University is given to practice passage as an opportunity to perform their own pedagogical, didactic and organizational activities. 240 hours of practice are integrated into the module "General qualification competences in Adult Education / Continuous Education" and are recommended to implement as soon as possible after the end of the second term. The practice should be implemented in pedagogical institutions, associations and enterprises with training and educational functions. Students must either choose practice place based on their own interests and their own experience or choose from a list of institutions offered by the department. For successful practice implementation it is recommended to have a practice agreement and an appointed practice supervisor. The main purpose of the Master's practice is to face the reality of professional activities in adult education and apply acquired andragogical knowledge. In addition, the positive aspects of the practice often increase students' motivation and job prospects opening. After the practice has been passed, students prepare a report of a reflective character as follows: personal justification of practice place choice; a description of the institution where the practice has been carried out; a description of his own practical activity; scientific self-analysis of own actions using literary sources; own achievements during practical training; conclusions on further education and professional development (Praktikum - Bereich Erwachsenenbildung, 2014).

The logical conclusion of Master' professional training is Master's thesis writing as it is a certain proof a student can carry out independent research within adult education using scientific methods. Preconditions of thesis writing are: at least 60 credits have been completed; a written petition for the appointment of the supervisor and the definition of the research topic. The preparation of the Master's thesis is given 6 months within the module "Master's thesis" with obligatory colloquium attendance (Studien - und Fachprüfungsordnung für den Masterstudiengang Erwachsenenbildung, 2012). If all examinations defined by the program have been successfully passed and Master's thesis has been defended, graduates receive a Diploma of Master of Arts, Diploma Supplement and Master's thesis review. Successful completion of academic education in Adult Education / Continuous Education entitles graduates to work in adult education with adult listeners, occupy leading positions and engage in teaching and program development. Masters in Adult Education can work in public schools, youth educational communities, educational enterprises, qualification centers, trade unions, political parties, with the production staff development of adults, that is, both the youth and people of middle and old age. In addition, after receiving Master's degree graduates entitle to continue their education as postgraduates for the dissertation preparation.

\section{CONCLUSIONS}

The theoretical analysis of the legal base in Germany has shown that the purpose of future andragogues' education is to prepare qualified specialists who must have profound 
knowledge in the field of adult education, four major professional competences and practical experience for further successful professional activity. Formation of professional competences is provided with the help of successful study of Master's program, based on the Basic Bachelor / Master's Program for pedagogical specialties in Adult Education / Continuous Education offered by Adult Education Sectional Commission of Pedagogical Sciences in Germany (DGfE). Comparing the programs offered by DGfE and Bamberg University, it has been found out that the university program fully complies with four blocks of the basic curriculum, omitting "Additional specialty". The results have proved that Master's program in Adult Education / Continuous Education in Otto Friedrich University in Bamberg is a consistent program with a slight variant character of curricula that do not allow students to choose a narrow specialization. The positive characteristics of the program include providing the importance to Masters' practical training. Theoretical analysis of module reference book has made it possible to define content component of andragogues' training in Bamberg University. Within the Bologna Process the students of the abovementioned specialty, on the one hand, have certain freedom of professional training organisation by independent planning of students' curriculum, based on the list of subjects; on the other hand, there are quite many hours of independent work. After the graduation, taking into account thorough professional training students are offered a wide range of professional activities and employment. Some fragments of the theoretical study during andragogues' professional training in Germany can be used for universities in Ukraine.

\section{REFERENCES}

1. Faulstich, P., Graeßner, G. (2005). Flexibilität mit Risiko - nicht ohne Nebenwirkung. Situation und Perspektiven des Hauptfachs Erziehungs - und Bildungswissenschaft: Schwerpunkt Erwachsenenbildung [Flexibility with risk - not without side effects. Situation and perspectives of the main subjects in education: focus on adult education]. Retrieved 20.08.2014 from : http:/www.diebonn.de/esprid/dokumente/doc-2005/graessner05_01.pdf (in German).

2. Faulstich, P., Zeuner, S. (2005). Vorschlag für Empfehlungen der Sektion Erwachsenenbildung der Deutschen Gesellschaft für ein Basisprogram EB/WB im Rahmen eines erziehungs- und bildungswissenschaftlischen Studiums mit dem Abschluss BA/MA [Proposal for recommendations of the Adult Education section of the German Society for a basic program EB / WB in the context of Educational Sciences eral studies with a BA / MA]. Erziehungswissenschaft: Zeitschrift, Volume 30, p. 35-43. Retrieved 20.10.2014 from : http://www.dgfe.de/fileadmin/OrdnerRedakteure/Service/Zeitschrift_Erziehungswiss enschaft/EW 30.pdf (Prof. Dr. Norbert Meder) (in German).

3. Kernprogram für konsekutive Bachelor - / Master-Studiengänge im Hauptfach Erziehungswissenschaft mit der Studienrichtung Erwachsenenbildung / Weiterbildung. (2006). [Core Program for consecutive Bachelor / Master's programs in Adult education / Continuous Education]. Retrieved 20.08.2014 from : http://www.dgfe.de/fileadmin/OrdnerRedakteure/Stellungnahmen/2006_KCE_EB WB_ko nsekutiv.pdf (in German).

4. Künzel, K., Keller, V. (2011). Wegbegleiter in die Erwachsenenbildung. Ein Studientext von Studierenden für Studierende und Sympathisanten [Companion in Adult Education. A students' research for students and sympathizers], p. 244 (in German). Retrieved 06.07.2014 from : www.hf.uni-koeln.de/file/7273. 
5. Modulhandbuch. Masterstudiengang Erwachsenenbildung / Weiterbildung. (2013). [Reference book. Master's program in Adult Education / Continuous Education]. Retrieved 21.07.2014 from : http://www.uni-bamberg.de/.

6. Praktikum - Bereich Erwachsenenbildung/Weiterbildung: Allgemeine und Fachspezifische Hinweise. Masterstudiengang EBWB von Otto-Friedrich Universität Bamberg. (2014). [Practice - Adult Education / Continuous Education: general and subjectspecific instructions. Master's Program AECE in Otto-Friedrich University of Bamberg]. Retrieved 21.07.2014 from : http://www.uni-bamberg.de (in German).

7. Praktikumsarbeit - Bereich Erwachsenenbildung/Weiterbildung: Allgemeine, formale und Fachspezifische Hinweise zur Abfassung. Masterstudiengang EBWB von Otto-Friedrich Universität Bamberg. [Practical work - Adult Education / Continuous Education: general, formal and subject-specific instructions for formulating. Master's Program AECE in Otto-Friedrich University of Bamberg]. (2014). Retrieved 21.07.2014 from : http://www.uni-bamberg.de (in German).

8. Schemmann, M., Wittroth, J. (2005). Gestufte Studiengänge und Professionalisierung der Erwachsenenbildung [Step-Sstudy and professionalisation of adult education]. Zeitschrift für Weiterbildungsforschung. Number 4 (28), p. 19-28. (Christiane Schiersmann) (in German).

9. Studien- und Fachprüfungsordnung für den Masterstudiengang "Erwachsenenbildung/Weiterbildung" (Adult and Further Education) an der OttoFriedrich-Universität Bamberg [Study and Examination Regulations for the Master's program in Adult Education / Continuous Education in Otto-Friedrich University of Bamberg]. (2012). Retrieved 21.07.2014 from : http://www.uni-bamberg.de (in German).

10. Walber, M., Graeßner, G. (2007). BA/MA Studiengänge zu Erwachsenen / Weiterbildung [BA / MA degree programs for Adult Education / Continuous Education]. Die Zeitschrift für Erwachsenenbildung. № 3, p. 20-21. Retrieved 12.06.2014 from : http://www.diezeitschrift.de/32007/index.asp (in German).

11.Бідюк, Н. (2014). Магістерська підготовка як складова професійного становлення молодого дослідника: британський та украйнський досвід [Master's Training as a part of young researcher's professional development: British and Ukrainian experience]. In : Бідюк, Н. М. (Ed.) Порівняльна професійна педагогіка [Comparative Professional Pedagogy]. Хмельницький : ХНУ №3 (Volume 4), p. 111-118 (in Ukrainian).

12. Лук'янова, Л. (2014). Професійна діяльність викладачів-андрагогів (зарубіжний досвід) [Professional activities of teacher-andragogue (foreign experience)]. In : Бідюк, Н. M. (Еd.) Порівняльна професійна педагогіка [Comparative Professional Pedagogy]. Хмельницький : ХНУ №3 (Volume 4), p. 119-123 (in Ukrainian). 